\title{
Identification of Suitable rhizobacterialspecies for Fluoride Contaminated Areas: A Comparative Growth Kinetics Study
}

\author{
Sheetal Trikha ${ }^{1}$, R. S. Chundawat ${ }^{2}$ \\ ${ }^{1,2}$ Department of Science, FASC, Mody University of Science and Technology (MUST) Lakshmangarh, Sikar, Rajasthan-332311 (India)

\begin{abstract}
Fluoride, not considered as a major toxicant earlier but now it is increasing very rapidly in soil. Rhizobacteria plays an important role in maintaining soil health and geo-chemical cycles. Previous studies indicate its effect on many enzymes affecting biochemical pathways, energy metabolism and growth at cellular levels. This study aimed to find out the best suitable rhizobacterial species for fluoride contaminated areas by comparing their growth kinetics and resistance to fluoride absorption. 19 rhizobacterial species were selected and allowed to grow in the presence of $15 \mathrm{ppm}$ fluoride. Growth kinetics and movement of fluoride from media to bacterial cells was monitored at different time intervals. Comparative growth fluctuation in presence of fluoride and respective control clearly indicates the significant interference of this mineral in rhizobacterial activity. Statistical analysis of data clearly indicates that P10 followed by P13 and P8 species can be more effective in improving soil health without using chemical fertilizers for fluoride contaminated areas.
\end{abstract}

Keywords: Fluoride; Rhizobacteria; Plant Growth Promoting Rhizobacteria (PGPR); Growth kinetics, Ion Selective Electrode (ISE).

\section{Introduction}

Fluorine is $13^{\text {th }}$ most abundant element on earth crust[20], forms binary compounds or salts known as fluorides which are ubiquitous in environment. Its concentration also increased due to its use in aluminum smelters, phosphate fertilizer plants, glass, brick, tile and plastic industries [8], [13], [29]. Fluoride exhibit adverse effects in animals and plants when present at applicable concentration have beenextensively studied [1], [6], [8], [21].

Rhizosphere is the narrow region of soil around the root of a plant body which is directly influenced by the root secretions and the associated soil microorganisms known as Rhizobacteria [28]. These bacteria promote plant growth by many ways like Nitrogen fixation, IAA production, phosphate solubilization,siderophore production etc.[27], [12], [10], [22]. In this way, these Plant Growth Promoting Rhizobacteria's (PGPR) play very beneficial role for the plant growth, mineralization of the soiland maintaining ecological cycles [5], [9], [14].

Although, fluoride occurs naturally in soil,it does not play any direct role in microbial growth and inadequate research has been done regarding the toxic effect of fluoride on soil microbial system [7], [16], [19], [26].The increase in fluoride affected areas during last decade, established a need to study the effects of fluoride as a toxicant on the soil microbial system, especially on rhizobacteria, as they play a vital role in ecological balance, soil health and plant growth. In present study, the growth kinetics of 19 rhizobacterial specieswascompared for their sensitivity towards fluoride, to select the most useful species for fluoride contaminated areas.

\section{Material and Methods}

To identify the fluoride resistant rhizobacteria, different species were screened for effect on growth and fluoride accumulation. The 19rhizobacterial strains were collected from IMTECH, Chandigarh.The selection of the rhizobacterial strain was based on their plant growth promoting activities. All the bacterial strains were grown on the nutrient broth media.

MIC determination: The minimal inhibitory concentration (MIC) of fluoride was determined by gradually increasing the concentrationof fluoride until the strains fail to form colonies on the plates.Viability was tested by CFU on agar plates [23]. $15 \mathrm{ppm}$ concentration was being selected for the present study.

Growth phase studies:Growth of all selected 19 strains was checked in presence and absence of fluoride. For this, the parent strains were fully grown in Nutrient broth media at $30^{\circ} \mathrm{C}$ for 30 hours at neutral $\mathrm{pH}$. Prepared Suspensions, used for inoculation were diluted to $0.08 \mathrm{~A}_{620} \mathrm{~nm}\left(1 \mathrm{x} \quad 10^{8}\right.$ cells $/ \mathrm{ml}$ )with fresh sterile media. ${ }^{2}$ The $500 \mu \mathrm{l}$ of the above prepared suspensions were inoculated in the growth media ( $\mathrm{pH}$ 7) used for control. For Toxicant effect, $15 \mathrm{ppm}$ fluoride concentration was developed by adding $\mathrm{NaF}$ to the media.Optical density was being taken at different time intervals up to 30 hours using Spectrophotometer at $620 \mathrm{~nm}$ for both control as well as toxicant simultaneously under same conditions. The experiment was performed in triplicate.

Fluoride Estimation: Ion Selective Electrode (ISE) of Thermo Scientific Orion Star Series meter was used for fluoride estimation. Fully grown cultures of $30 \mathrm{~h}$ incubation were centrifuged to separate media and bacterial cells. Both the components were dissolved in triple acid and before taking the readings in ISE, then adjusted the $\mathrm{pH}$ of the digested sample to neutral from the acidic $\mathrm{pH}$ and finally 


\section{International Journal of Science and Research (IJSR) \\ ISSN (Online): 2319-7064}

Index Copernicus Value (2013): 6.14 | Impact Factor (2014): 5.611

prepared the sample solution in 1:10 ratio with the total-ionic strength adjustment buffer (TISAB) buffer [18].

Statistical Analysis: Data was subjected to analysis of variance (ANOVA) at $\mathrm{p}<0.05$. From this, least significant difference (LSD) was calculated [24].The value of LSD calculated indicate the minimum difference, which ought to be there for a significant difference to exist between any two groups that were compared. Ranking correlation was applied to identify the best bacterial species in presence of fluoride [11].

\section{Results}

Fluctuation in growth: Growth data was collected from all the selected species in presence of fluoride at 3, 6, 9, 12, 24, 27 and 30 hours incubations. Control was considered as $100 \%$ and any fluctuation due to fluoride presence were shown in graphs (Figure 1- 6). All the selected 19 rhizobacterial species show significant decrease in growth at each interval of time due to the presence of fluoride. Maximum significant decrease $18 \%$ was observed in P14 establishing their sensitivity towards fluoride after 27 hours. The rest other species also showed significant reduction in growth except P10 which have demonstrated non significant decline in growth after 27 hours.

Alteration of fluoride concentration: The fluoride movement was observed by estimating media and cell pellet separately after 30 hours incubation. $15 \mathrm{ppm}$ was considered as $100 \%$ for media and any fluctuation in concentration after 30 hours is expressed in graph. The results clearly indicate that fluoride was absorbed by the bacterial cell so there was significant drop in media fluoride concentration (Figure 7). Simultaneously, significant fluoride absorption by bacterial cells was observed. There may be inbuilt resistance in P10 strain towards fluoride and thus the very less growth fluctuation was observed in comparison to its control during its growth profile study (Figure 8)

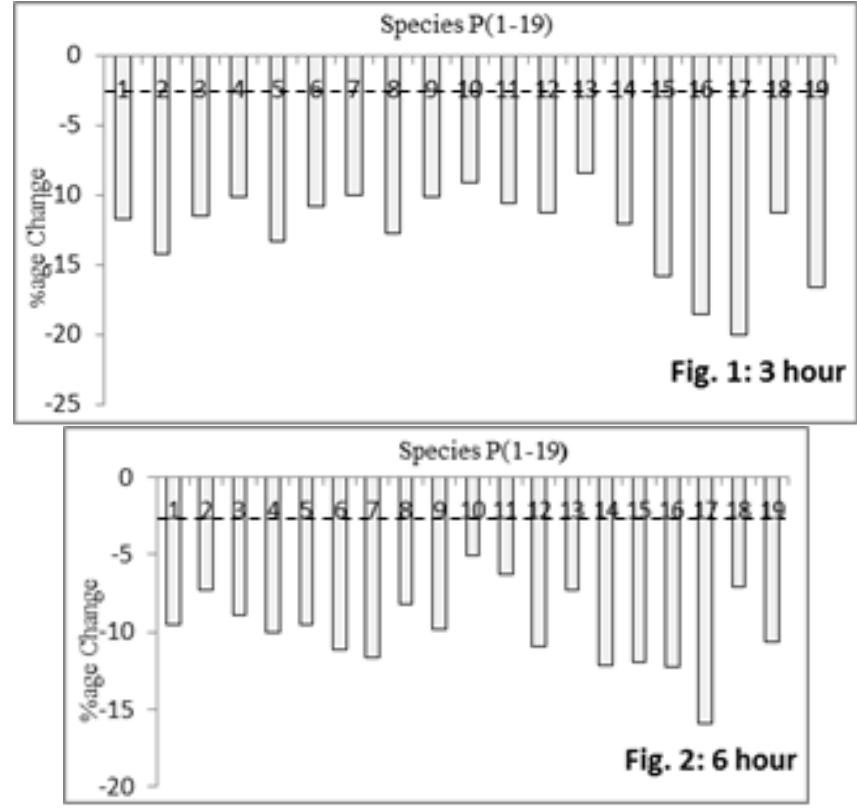

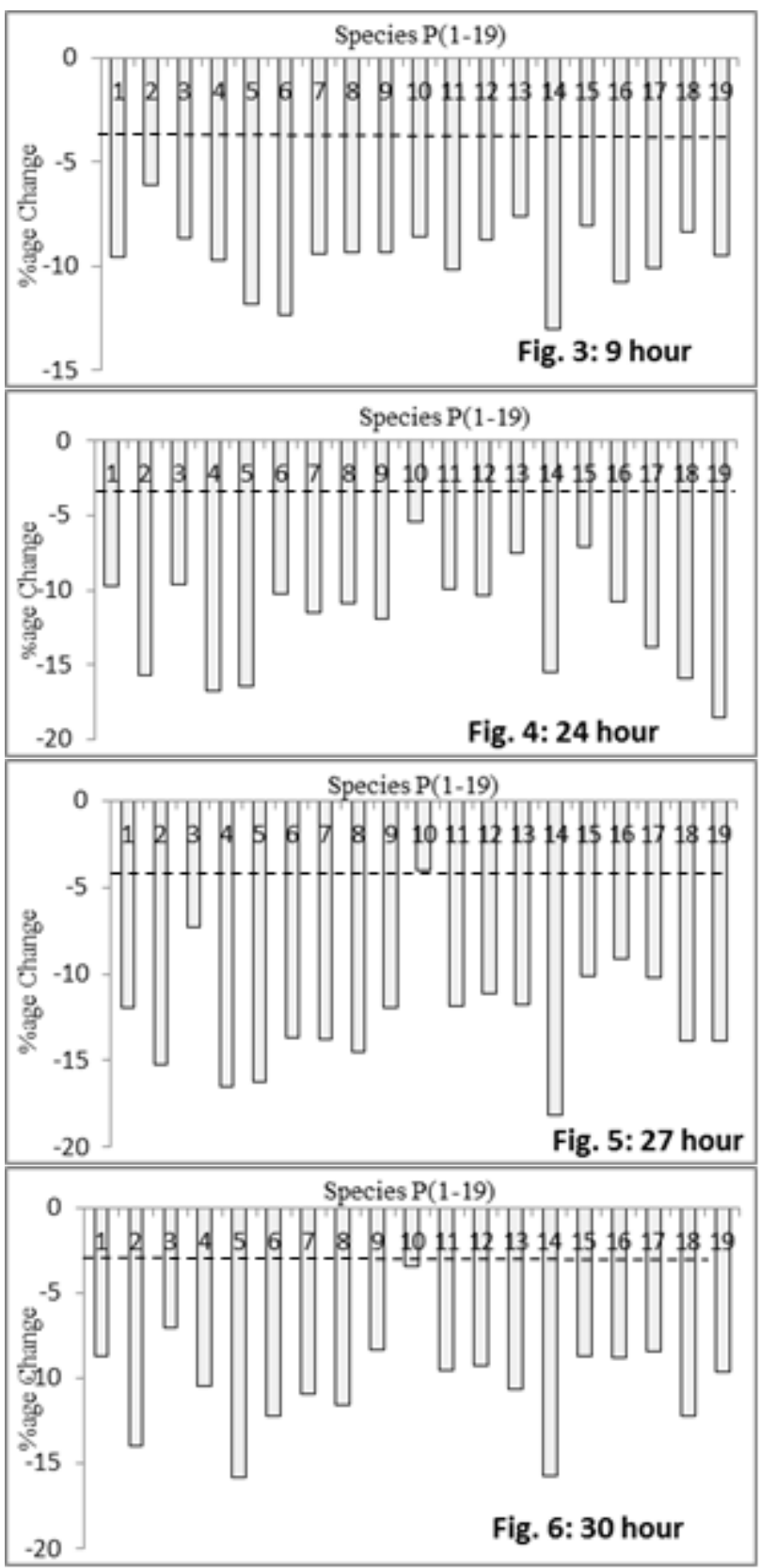

Figure (1-6): represent the fluctuation in growth at different intervals of incubation. Control is considered as $100 \%$ and fluctuation is shown in different $\mathrm{P}(1-19)$ species. Significance $(\mathrm{P}<0.05)$

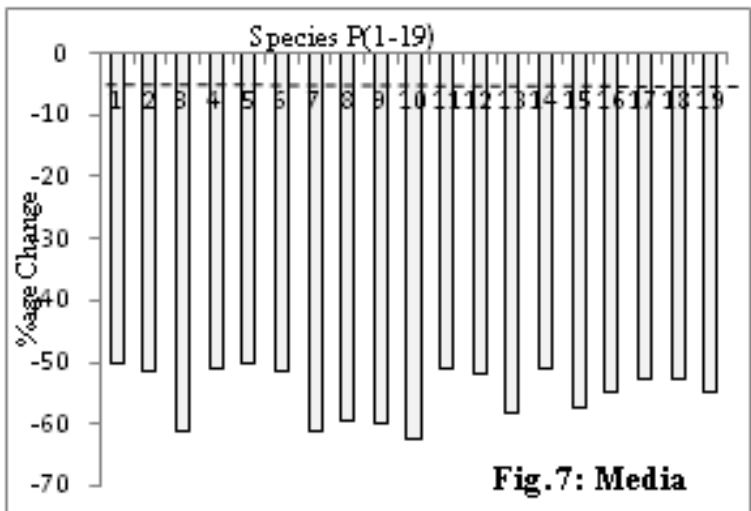




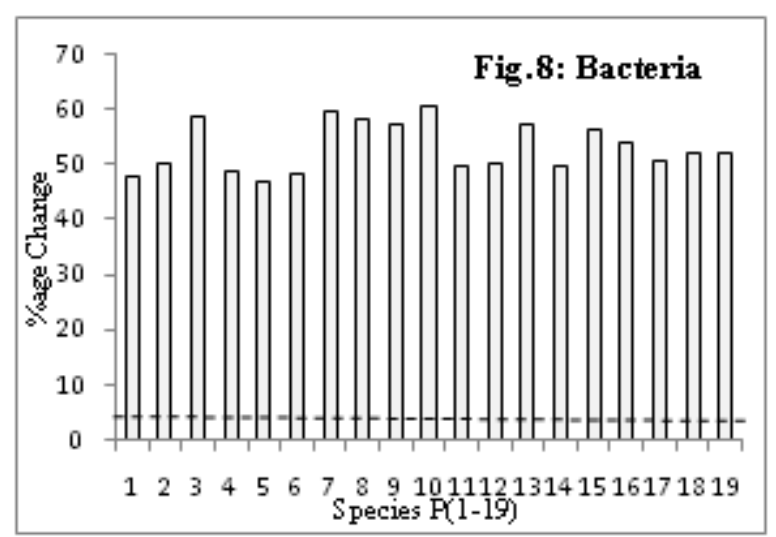

Figure (7-8): Shows decrease in fluoride concentration from media and increase in fluoride concentration in bacterial cells respectively after 30 hour of incubation.

The Rank Correlation analysis of fluoride absorption and growth establish that P10 is the best suitable species as it resists against fluoridepresence and grow almost equivalent to the respective control. The ranking order of the nineteen selected species on the basis of correlation analysis is:

$\mathrm{P} 10>\mathrm{P} 13>\mathrm{P} 8>\mathrm{P} 18>\mathrm{P} 7=\mathrm{P} 9>\mathrm{P} 2=\mathrm{P} 3=\mathrm{P} 11=\mathrm{P} 19>$

$\mathrm{P} 15>\mathrm{P} 1=\mathrm{P} 17>\mathrm{P} 16>\mathrm{P} 4=\mathrm{P} 5=\mathrm{P} 12>\mathrm{P} 6>\mathrm{P} 14$

\section{Discussion}

The toxicological studies of various bacterial species indicate difference in response to the same toxicant due to variation in their genetic capacities. In the present study, diversified response was observed in different rhizobacterial species in presence of fluoride with respect to the growth and fluoride permeability. In soil, fluoride enters bacterial cell mainly in the form of HF [15]. Fluoride ones enter in cell cause cytoplasmic acidification and acidic inhibition of both catabolic and biosynthetic enzymes [25]. After entering the microbial cell these metals ions react with the target molecule and may cause lipid per-oxidation, makes various complexes, binds to the active sites of various enzymes, altering its functionality,leads to the disturbance of various metabolic pathways which ultimately reduces the antioxidant level of the cell and causes oxidative stress.

This intracellular fluoride mainly interferes with the energy metabolism pathways like glycolysis by inhibiting an important enzyme enolase and results in the reduction of Pyruvate and ATP which not only causes loss in energy currency but also interferes with sugar transport, causes decrease in cell growth [4], [14],[25]. Bacterial cells fight against toxicant, by its glutathione pool and try to maintain its internal homeostasis, but when stress is much higher it leads to the decrease in colony forming units (CFU), causes cell death and as a consequence overall productivity decreases. Therefore, maximum selected rhizobacterial species demonstrated decrease in the growth with the accumulation of the fluoride.

There are many types of genes which are associated with fluoride riboswitches (mRNA's). Basically these riboswitches, which are associated with various genes, are responsible for the fluoride resistance among microbes [3]. Every bacterial cell doesn't have the full spectrum of these genes, thus, their response and resistance capabilities vary accordingly. Microbes evolve various mechanisms in response to change in environmental conditions. The resistant species evolve mechanisms for efflux, complexation or reduction of metal ions or to use them as terminal electron acceptors in anaerobic respiration [17]. This evolution capacity empowers the species to grow better in presence of toxicant.

\section{Conclusion}

In the comparative analysis of 19 rhizobacterial species in response to the fluoride presence, species P10 established the better capacity of growth.

\section{Future Scope}

P10 followed by P13 and P8 can be used for fluoride rich area due to their better growth capacity and fluoride absorption capacity.

\section{Author Profile}

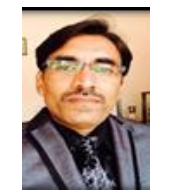

Dr. R. S Chundawat is presently working as an Assistant professor, in Department of Science, ModyUniversity of science and technology, Lakshmangarh,Rajastahn, India. $\mathrm{He}$ is actively engaged in research (experimental Biology and Toxicology) as well as teaching for last 13 years. He did M.Sc in zoology and Ph.D in toxicology from Dept. of Bioscience,Saurashtra University, Rajkot. He also received PostDoctoral Fellowship of ICMR in 2003. Heavy metal toxicity and protection is the core area of his research and he has published about 16 research articles in various scientific journals of international repute. Further he is also associated with the publication of journal of cell and tissue research, journal of herbal medicine and toxicology, journal of environmental science. His research is also presented in various international and national conferences, seminar and symposiums. He is a member of various scientific societies and institutional committees.

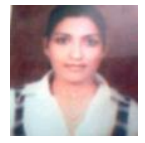

Sheetal Trikha is Research scholar under guidance of Dr. R.S.Chundawat from Mody University of Science and technology, Lakshmangarh, Rajasthan, India since 2012. Her Ph.d research work is related to the microbial toxicology. She has done master's in Biotechnology from D.A.V. CollegeAbohar under Panjab University.

\section{References}

[1] M. Baunthiyal ,S. Ranghar,"Physiological and biochemical responses of plants under fluoride stress: An overview,"Fluoride,(47), pp. 287-293, 2014.

[2] T.V.Bhuvaneshwari , B.G. Turgeon ,B.D. Wolfgang, " Early events in the infection of soyabean (Glycine max L.Merr) by Rhizobium japonicum,"Plant Physiology (66) pp. 1027-1031, 1980.

[3] R.R. Breaker,"New insight on the response of bacteria to fluoride,"Caries Research,(46) pp. 78-81,2012.

[4] H.L. Byers, K.A. Homer,E. Tavelli , D. Beighton,"Nacetylneuraminic acid transport by Streptococcus oralis strain AR3,"Journal of Medical Microbiology, (48) pp. 375-38, 1999 .

\section{Volume 4 Issue 12, December 2015}




\section{International Journal of Science and Research (IJSR) \\ ISSN (Online): 2319-7064}

Index Copernicus Value (2013): 6.14 | Impact Factor (2014): 5.611

[5] B.A. Caldwell, " Enzyme activities as a component of soil biodiversity: A review,"Pedo biologia, (49)pp. 637644,2005 .

[6] S.L. Choubsia, " Status of fluorosis in animals,"Proceedings inNational Academy of Sciences, India," Section B Biological Sciences 82(3), pp. 331339,DOI 10.1007/s40011-012-0026-0, 2012.

[7] S. Chouhan, U. Tuteja, S. J. Flora, "Isolation,identification and characterization of fluoride resistant bacteria: Possible role in bioremediation,"Applied Biochemistry and Microbiology, (48) pp. 51-58, 2012.

[8] S.J. Cronin, V. Manoharan, M.J. Hedley, P. Loganathan," Fluoride: A review of its fate, bioavailability, and risks of fluorosis in grazed-pasture systems in New Zealand," New Zealand Journal of Agricultural Research (43) pp. 295-321, 2000.

[9] P.G. Falkowski, T. Fenchel, E.F. Delong, "The microbial engines that drive earth's biogeochemical cycles,"Science ,(320), 2008.

[10] W. Frankenberger ,M. Arshad,Phytohormones in soils: Microbial production and function. New York,Marcel Dekker;1995.

[11] S.P. Gupta, M. P. Gupta, Business Statistics.10 ${ }^{\text {th }}$ ed. Delhi, India, 2010.

[12] C.R. Howell, R.C. Beier, R.D. Stipanovic,"Production of Ammonia by Enterobacte cloacae and its possible role in the biological control of Phythium pre-emergance damping- off by the bacterium," Phytopathology, (78) pp. 1075-1078, 1998.

[13] S. Jagtap , M.K. Yenkie, N. Labhsetwar, S. Rayalu, "Fluoride in Drinking Water and Defluoridation of Water,"Chemical Review, (112)pp. 2454-2466. 2012.

[14]E.L. Madsen, "Microorganisms and their role in fundamental biogeochemical cycles," Current Opinion in Biotechnology, (22) pp. 456-464, 2011.

[15]R.E. Marquis, S.A. Clock , M.M. Meira . Fluoride and organic weak acids as modulators of microbial physiology. FEMS Microbiology Reviews 2002.

[16] N.K. Mondal, K.C. Pal, M. Dey, S. Ghosh, C. Das, J.K. Datta, "Seasonal variation of soil enzymes in areas of fluoride stress in Birbhum district, West Bengal, India," Journal of Taibah University of Science, (9) pp. 133$142,2015$.

[17] D.H. Nies, "Microbial heavy metal resistance,"Applied Microbiology and Biotechnology, (51) pp.730-750, 1999.

[18]NIOSH Manual of Analytical Methods. 4th Edn., Cincinnati; 1994.

[19] K.C. Pal, N.K. Mondal, S. Chatterjee, T.S. Ghosh, J.K. Datta, "Characterization of fluoride-tolerant halophilic Bacillus flexus NM25 (HQ875778) isolated from fluoride-affected soil in Birbhum district, West Bengal, India," Environment Monitering Assessment,2014;(186) pp. 699-709, 2014.

[20]P.K. Rakshit, "Studies on estimation of fluoride and fluoridation of drinking water," Dissertation , IISc Bangalore;2004.

[21] A. Ram, P. Verma, B.R. Gadi, "Effect of fluoride and salicylic acid on seedling growth and biochemical parameters of watermelon (Citrullus lanatus),"Fluoride, (47) pp. 49-55, 2014.
[22]H. Rodriguez, R. Fraga, " Phosphate solubilising bacteria and their role in plant growth promotion,"Biotechnology Advances, (17) pp. 319-339, 1999.

[23]A.R. Shakoori, K.S. Zaidi, "Cadmium resistant Enterobacter clacae and Klebsiella sp isolated from industrial effluents and their possible role in cadmium detoxification,"World Journal of Microbiology and Biotechnology, (15) pp. 249-254, 1998.

[24]R.R. Sokal, F.J Rohlf, Biometry: the principles and practice of statistics in biological research. San francisco, 1969.

[25]H.S. Spets, L. Seppa, A. Korhonen, P. Alakujala, " Accumulation of strontium and fluoride in approximal dental plaqueand changes in plaque microflora after rinsing with chlorohexidine-fluoride-strontium solution,"Oral diseases, (4)pp. 114-119, 1998.

[26]D. Tscherko ,E. Kandeler, " Ecotoxicological effects of fluorine deposits on microbial biomass and enzyme activity in grassland,"European Journal of Soil Science ,(48) pp.329-335, 1997.

[27] D.P. Verma, M.G. Fortin, J. Stanley, V.P. Mauro, S. Purohit, N. Morrison," Nodulins and nodulin genes of Glycine max,"Plant Molecular Biology , (7) pp. 51-61, 1986.

[28] J.K. Vessey," Plant growth promoting rhizobacteria as biofertilizers,' Plant and Soil, (255) pp. 571-586, 2003.

[29] F.V. Zohoori, P.J. Moynihan, N. Omid, L. Abuhaloob, A. Maguire, "Impact of water fluoride concentration on the fluoride content of infant foods and drinks requiring preparation with liquids before feeding,"Community Dental Oral Epidemiology, (40) pp. 432-440, 2012. 